\title{
Kessler, D (ed) 1999 - Together on the Way: official report of the eighth assembly of the World Council of Churches.
}

Geneva: World Council of Churches. Soft Cover. 406 Pages. Price: US\$19.95

\section{Reviewer: Dr G M J van Wyk}

An official report of an assembly of the WCC is certain to be a publication of great significance for the ecumenical movement and the broader church in our time. Each of the WCC's assemblies has had its own particular profile. These diverse profiles are also reflected in each of the reports of the eight assemblies. The General Secretary of the WCC, Konrad Raiser, said about the eighth assembly: "The Harare assembly was marked by its setting on the African continent, by the theme "Turn to God - Rejoice in Hope", echoing the biblical jubilee motif, and by the celebration of the $50^{\text {th }}$ anniversary of the WCC". There were indeed reasons for jubilation at this assembly, but this does not mean that there were not also reasons for great concern. The future of the ecumenical movement, and particularly of the WCC, is not very clear. Raiser expressed his concerns about the future of the movement by saying: "Despite the broad-based and constructive participation of member churches and ecumenical partners in the nine-year process of reflection about a "common understanding and vision of the World Council of Churches" fears had been expressed prior to the assembly about the future of the World Council. Eastern Orthodox churches in particular had expressed critical concern". For this reason it was important that the assembly would respond with a message of hope. Some delegates felt it was important to send a message to the world that, during the eighth assembly, members of the WCC not only were together, but also were moving together and building together.

The main body of the book contains eight chapters. First, there is an introduction and personal perspective, written by Kessler (1), followed by three meditations printed under the theme of the assembly, "Turn to God - Rejoice in hope" (2). These are "Anamnesis" by Anastasios, "Metonoia" by Wanda Deifelt and "Rejoice in Hope" by Kosuke Koyama. A third chapter (3) deals with the work of the WCC. This chapter includes the reports by the Moderator, General Secretary, the Finance Committee and the Programme Guidelines Committee. The fourth chapter (4) includes, among other topics, the report of the Policy Reference Committee and a section on the relationship with Orthodox Churches. "Actions on issues of current global concern" is the title of the fifth chapter (5). This chapter not only deals with the reports of the Policy Reference Committee and the Public Issues Committee, but also includes documents and statements on the debt issue of poor countries, globalisation, child soldiers, the status of Jerusalem, the universal declaration of human rights and a statement on human rights. The last three chapters deal with (6) the African context of the assembly, (7) greetings from religious and political leaders, and (8) additional documents, such as the reports on Sudan (Appendix I) and Globalisation (Appendix II) by the Policy 


\section{Boekbesprekings / Book Reviews}

Reference Committee. The last chapter ends with a paper by Philip Potter, the General Secretary of the WCC from 1972 to 1984 , on "Visions for the Future". A preface to the book was written by the current General Secretary, Konrad Raiser. The preface is followed by "The Assembly Message: Being together under the Cross in Africa". The book is rounded off with appendixes. Included in the appendixes are lists of participants, assembly committees, chairpersons, member churches, and so forth. The Constitution and Rules of the WCC as amended by the assembly are also included as an appendix.

To give the prospective reader of the report a feeling of the profile of the content, I end this review with a quotation from the Assembly Message:

From this eighth assembly of the World Council of Churches we share with you, our brothers and sisters, a message of hope. The God who has called us together will bring us to the fulfilment of all things in Christ. The jubilee which has begun among us is sent to you, to celebrate the liberation of the entire creation. As we have turned once again to God, we have been able to rejoice in hope. We invite you to share with us the vision which we have been able to express together and which, we pray, will become part of a common life and witness:

We long for the visible oneness of the body of Christ. affirming the gifts of all. young and old, women and men, lay and ordained.

We expect the healing of human community, the wholeness of God's entire creation.

We trust in the liberating power of forgiveness, transforming enmity into friendship and breaking the spiral of violence.

We are challenged by the vision of a church that will reach out to everyone.

sharing, caring, proclaiming the good news of God's redemption, a sign of the kingdom and a servant of the world.

We are challenged by the vision of a church, the people of God on the way together confronting all divisions of race, gender, age or culture, striving to real justice and peace, upholding the integrity of creation.

We journey together as a people with resurrection faith. In the midst of exclusion and despair we embrace, in joy and hope, the promise of life in all its fullness. 


\section{Boekbesprekings / Book Reviews}

We journey together as a people of praver.

In the midst of confusion and loss of identity,

we discern signs of God's purpose being fulfilled

and expect the coming of God's reign.

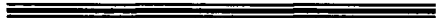

